\title{
PENGARUH LOKASI USAHA, MODAL DAN PENDAPATAN TERHADAP KESEJAHTERAAN INDIVIDU PEDAGANG KAKI LIMA
}

(Studi Pedagang Kaki Lima di Pasar Kaget Kawasan Palem Semi

Kota Tangerang)

\author{
Sugina $^{1}$, Selamat Zebua ${ }^{2}$, Mulyati ${ }^{3}$, Dhea Ayu Ramadhina ${ }^{4}$ \\ 1234 Fakultas Ekonomi dan Bisnis, Universitas Tangerang \\ sugina@raharja.info, selamat.zebua@,raharja.info
}

\begin{abstract}
ABSTRAK
Tujuan penelitian untuk mengetahui pengaruh lokasi usaha, modal dan pendapatan secara parsial maupun secara simultan terhadap kesejahteraan individu pedagang, metode penelitian berjenis kuantitatif dengan metode sampling ialah sampel random sampling menggunakan rumus slovin gradasi 5\%, populasi yang diambil sampel sebesar 136 responden, hasil penelitian ini menunjukkan pengaruh Lokasi usaha (X1) terhadap kesejahteraan individu pedagang (Y) sebesar $18,14 \%$ berkategori positif dan kuat, pengaruh Modal (X2) terhadap kesejahteraan individu pedagang (Y) sebesar 16,32\% berkategori positif dan kuat, pendapatan (X3) terhadap kesejahteraan individu pedagang (Y) sebesar 16,32\% berkategori positif dan kuat serta pengaruh simultan Lokasi usaha (X1), Modal (X2) dan Pendapatan (X3) terhadap kesejahteraan individu pedagang (Y) sebesar $18,66 \%$ berkategori positif dan kuat.
\end{abstract}

Kata kunci : Lokasi usaha, Modal, Pendapatan dan Kesejahteraan Individu pedagang

\section{PENDAHULUAN}

Indonesia dalam era globalisasi saat ini, kini terdampak suatu wabah covid-19, dimana wabah covid-19 terjadi pada era persaingan, oleh karena itu, kesulitan mencapai kesejahteraan bagi warga negara Indonesia masih jauh dari kata cukup sejahtera (individu), sehingga tidak dapat menikmati dimana ajang persaingan dunia kerja menuju kesejahteraan masyarakat global, selain itu, permasalahan kesejahteraan juga dikarenakan perilaku pasar yang biasa di jalankan oleh seluruh warga negara baik sebagai penggerak ekonomi maupun pedagang eceran (kaki lima) yang berada dalam kategori pandemic covid-19, seiring itu, perberlakuan pembatasan kegiatan masyarakat di Indonesia sehingga penekanan seluruh aktivitas lebih terbatas.

Keterbatasan kegiatan dirasakan khususnya oleh warga pedagang kaki lima di wilayah kota Tangerang, untuk mempertahankan ekonomi guna mencapai kesejahteraan dari penghidupan yang layak pun menjadi kendala saat pandemic ini, dikatakan oleh (Kustiadi, 2017) bahwa kesejahteraan dapat dilihat dari kesejahteraan objektif dan subjektif baik secara individu maupun kelompok, dimana keduanya terkait dengan kehidupan aktivitas ekonomi masyarakat dengan patokan tertentu, seperti kesejahteraan objektif individu ialah kebahagiaan. 
Tabel 1.1 Status pedagang kaki lima di Kawasan palem semi kota Tangerang

\begin{tabular}{|c|l|c|c|c|c|}
\hline No & Variable & $\begin{array}{c}\text { Penjual } \\
\text { pakaian }\end{array}$ & $\begin{array}{c}\text { Penjual buah- } \\
\text { buahan }\end{array}$ & $\begin{array}{c}\text { Penjual sayur } \\
\text { mayur }\end{array}$ & Jumlah \\
\hline 1 & Laki-laki & 67 & 29 & 35 & 131 \\
\hline 2 & Perempuan & 48 & 6 & 21 & 75 \\
\hline
\end{tabular}

Sumber data : Observasi lapangan, Nov 2021

Kesejahteraan hidup individu dapat dicapai dengan segala aktivitas masyarakat itu sendiri, akan tetapi dimasa pandemic secara terbatas telah diterapkan, oleh karena itu, berbagai usaha yang dilakukan dapat berbentuk seperti pengadaan kreasi usaha mikro yang menjadi pilihan tersendiri saat ini, yaitu dengan membuka pasar kaget, dimana bentuk aktivitas bersama pedagang kaki lima dengan kegiatan yang dilakukan baik kelompok maupun individu pada waktu tertentu, dengan demikian, kegiatan para pedagang kaki lima pasar kaget mengharapkan mencapai kesejahteraan.

Pedagang ialah pelaku perdagangan, perdagangan mencakup segala kegiatan tukar menukar, baik barang dengan barang maupun barang dengan uang (Yusanto, 2000). Sedangkan pasar kaget ialah pasar sesaat, pasar dadakan yang berdiri dengan waktu tertentu (Sudriwati, 2017). Dengan begitu, pedagang kaki lima pasar kaget ialah kegiatan perdagangan dengan pelaku menjual dan tukar menukar antara barang dengan uang pada suatu tempat waktu tertentu.

Pedagang kaki lima pasar kaget merupakan para pelaku kegiatan perdagangan yang waktu dan lokasi serta modal tidak dapat diprediksi akan tetapi kegiatan pasar kaget tersebut tidak dilakukan sehari-hari.

Namun kegiatan para pedagang tersebut dilakukan secara terbatas, pembatasan aktivitas masyarakat seiring dengan kegiatan aktivitas pedagang yang hanya dilakukan pada pagi hari tertentu saja, disebut pedagang kaki lima melakukan perdagangan pada malam tertentu saja.

Permasalahan kesejahteraan hidup pegadang kaki lima di masa saat ini belum tercapai kelayakannya, permasalah kesejahateraan ini dapat di asumsikan dikarenakan lemahnya lokasi usaha yang dipilih tidak dapat izin sehari-hari dan tentu kegiatannya hanya sebatas waktu minggu pagi saja, kendalanya lokasi usaha juga disebabkan terbatasnya lokasi usaha yang disediakan oleh pemerintah setempat, selain itu, permasalahan kesejahteraan juga di sebabkan karena modal pedagang untuk membuka dan mengenbangkan usaha masih minim, minimnya modal dirasakan sangat kesulitan mendapatkan bantuan lembaga lainnya, bahkan modal yang di gunakan berasal dari modal divide, dimana modal yang ada menjadi harapan kelayakan hidup menuju kesejahteraan keluarga.

Kegiatan yang dilakukan pedagang kaki lima pasar kaget utamanya ialah berjualan dengan pertukaran barang dengan uang, dimana pendapatan yang dituju ialah uang sebagai sumber masukan pendapat pedagang tersebut, kelemahan pendapatan dirasakan disebabkan pembeli yang mulai berkurang dan terbatasnya kehadiran pembeli, khususnya kegiatan pedagang kaki lima di Kawasan Palem Semi Kota Tangerang. 
Tujuan penelitian ini untuk mengetahui bagaimana pengaruh secara parsial maupun simultan antara lokasi usaha, modal dan pendapatan terhadap kesejahteraan individu pedagang kaki lima pasar kaget di Kawasan palem semi kota Tangerang. Metode yang gunakan sebagai acuan konsep penelitian ini berjenis penelitian kuantitatif dengan pendekatan deskriptif, dimana peneliti bermaksud memperdalam dengan permasalahan kesejahteraan individu pedagang kaki lima pasar kaget di Kawasan palem semi kota Tangerang.

Berdasarkan permasalahan kesejahteraan yang dikemukan tersebut diatas, penulis lebih tertarik meneliti pengaruh lokasi usaha, modal dan pendapatan terhadap kesejahteraan individu pedagang kaki lima pasar kaget di Kawasan palem semi kota Tangerang.

\section{Landasan teori}

\subsection{Pasar kaget di Kawasan palem semi kota Tangerang.}

Kota Tangerang merupakan salah satu kota terbesar di provinsi Banten serta ketiga terbesar di kawasan Jabodetabek setelah Jakarta dan Bogor. Kota Tangerang melingkupi Kawasan Palem Semi yaitu sebagian wilayah perumahan yang berada di antara kelurahan Panunggangan Barat kecamatan Cibodas kota Tangerang dengan Kelurahan Bencongan Indah, kecamatan Kelapa Dua kabupaten Tangerang.

Pasar kaget tertuang dalam PP 112 tahun 2007 (Abd. Azis, 2017), sedangkan pengertian pasar kaget dari pasar tradisional yaitu pasar yang dibangun dan dikelola oleh pemerintah yaitu Pemerintah Daerah, Swasta, Badan Usaha Milik Negara dan Badan Usaha Milik Daerah termasuk kerjasama dengan swasta dengan tempat usaha berupa toko, kios, los dan tenda yang dimiliki/dikelola oleh pedagang kecil, menengah, swadaya masyarakat atau koperasi dengan usaha skala kecil, modal kecil dan dengan proses jual beli barang dagangan melalui tawar menawar.

Keberadaan pasar kaget di Kawasan palem semi kota Tangerang berawal dari pemikiran kelompok pegadang yang mendapati izin warga yang disambut hangat dengan populasi warga sebesar 117,676 jiwa atau kartu keluarga sebanyak 2.001 rumah tangga, untuk sekitar luas Kawasan palem semi kota Tangerang sekitar berjumlah $9,54 \mathrm{~km}^{2}$ yang berdekatan dari enam kelurahan. Lokasi stategis palem semi bersebelahan dengan kecamatan Cibodas kota Tangerang di bagian utara Kecamatan Karawaci dan Kecamatan Tangerang Timur Kecamatan Karawaci dan Kecamatan Pinang Selatan Kecamatan Kelapa Dua Barat Kecamatan Periuk dan Kecamatan Jatiuwung.

Penelitian sebelumnya oleh (Siti, 2014), tentang "Pengelolaan Pasar Tradisional Berbasis Musyawarah untuk Mufakat". Penelitian tersebut berawal dari fenomena adanya Pasar Kaget Rukun Asih yang berdiri pada tahun 1999, terletak di wilayah Gempol Sari Kecamatan Bandung Kulon. Status Pasar Kaget Rukun Asih yang tidak dikelola oleh Pemerintah maupun Perusahaan Swasta menjadikan pengelolaan Pasar Kaget Rukun Asih ini menjadi tanggung jawab masyarakat Gempol Sari Pasar merupakan sesuatu yang akrab dengan kehidupan masyarakat, baik di kota maupun di desa karena di pasar kita dapat memperooleh berbagai barang untuk kebutuhan hidup. Pasar menjadi pusat perdagangan yang 
sangat aktif dan meliputi daerah yang amat luas, lewat pasar itu segala macam dagangan disalurkan dan dari pasar itu pula sebagian penduduk kota mendapat mata pencahariannya.

\subsection{Kesejahteraan individu pedagang}

(Jauhari, 2009) menyebutkan bahwa kesejahteraan merupakan hal penting yang harus diperhatikan pada organisasi, di karenakan rata-rata orang dewasa yang bekerja sebagai pedagang, lebih banyak menghabiskan waktu di lokasi usaha (tempat kerja), dan hal tersebut menjadi bagian penting dari rutinitas para pedagang yang akan mempengaruhi kesejahteraan mereka. Oleh karena itu, pedagang akan berusaha mencapai kesejahteraan individunya sebagaimana yang mereka harapkan.

Menurut Lokshin dan Ravallion dalam (Kustiadi, 2017) mengenai kesejahteraan dilihat dari dua kategori yaitu kesejahteraan objektif dan kesejahteraan subjektif. Kesejahteraan subjektif dapat menggambarkan berbagai aspek dalam kehidupan, antara lain terkait lapangan pekerjaan, aktivitas ekonomi, tingkat independensi, semangat hidup, dan leisure. Di perjelas dengan pendapat (Suandi, 2007) yang mengatakan bahwa kesejahteraan subjektif merupakan tingkat kesejahteraan seorang individu yang dilihat secara personal yang diukur dalam bentuk kepuasan dan kebahagiaan.

(Zela, 2019) mengkategorikan bahwa kesejahteraan secara subjektif merupakan penilaian diri terhadap kesejahteraan yang di alami individu. Oleh sebab itu, penulis mengatakan bahwa kesejahteraan subjektif individu yang baik merupakan keinginan setiap manusia yang dapat di capai. Namun, kesejahteraan subjektif juga menjadi permasalahan yang cukup memprihatinkan bagi pedagang khususnya pedagang kaki lima, di karenakan pekerjaan para pedagang kaki lima di dalam menjalankan rutinitas kegiatannya sering terpapar dengan kesusahan, kesulitan dan hambatan dari hasil yang maksimal.

\subsection{Lokasi usaha}

Seorang pemilik usaha berusaha untuk menentukan tempat yang tepat harus mempertimbangkan faktor-faktor tempat berikut dalam mengambil keputusan: (1) area pasar, (2) cakupan pasar, dan (3) tata letak dan desain tempat usaha. Lokasi usaha sangatlah penting karena membantu dalam menentukan bauran konsumen dan persaingan. Sekali lokasi usaha (Sumaatmadja, 2008) dipilih maka akan sulit untuk memindahkannya, sebab kalau lokasi sering berpindaha akan menyebabkan kurangnya, pelanggan. Lokasi usaha merupakan salah satu keputusan bisnis yang harus dibuat secara hati-hati, dimana untuk mencapai kesuksesan usaha pedagang yang diharapkan.

Penelitian-penelitian terdahulu menemukan bahwa lokasi usaha berhubungan dengan kesuksesan usaha tersebut, lokasi usaha merupakan salah satu keputusan bisnis yang harus dibuat secara hati-hati. Penelitian-penelitian terdahulu menemukan bahwa lokasi usaha berhubungan dengan kesuksesan usaha tersebut (Swastha, 1990). Dari uraian di atas dapatlah ditegaskan bahwa lokasi usaha merupakan hal yang cukup penting dan harus dipertimbangkan dengan matang 
oleh produksen dalam upaya untuk memperoleh keuntungan maupun demi kelangsungan usaha

Selain itu menurut Carthy dan Parreault dalam memasarkan barang dagangan sebaiknya memilih lokasi seperti :

a. Pusat pembelanjaan yang terencana yaitu perkumpulan toko yang direncanakan sebagai suatu unit untuk memenuhi kebutuhan pasar karena toko toko tersebut biasanya melakukan promosi bersama.

b. Pusat pembelanjaan yang dekat dengan perumahan yang terdiri dari beberapa toko kebutuhan sehari hari.

c. Pusat pembelanjaan masyarakat, karena di sini pedagang kaki lima bisa mempunyai kesempatan yang lebih besar untuk menarik konsumen karena padatnya populasi. (Charty E, 1993).

\subsection{Modal}

Teori modal (Cahyono, 2014) dicetuskan pertama kali oleh Piere Bourdieu. Disebutkan bahwa teori ini mempunyai ikatan erat dengan persoalan kekuasaan, khususnya penguasaan barang untuk di perjualkan menjadi bentuk kas sebagai modal (Irawan, 2005). Oleh karenanya pemikiran Bourdieu terkonstruk atas persoalan dominasi penguasaan modal. Fungsi modal adalah relasi kebutuhan dalam sebuah sistem pertukaran, yang mempresentasikan dirinya sebagai sesuatu yang langka, yang layak dicari dalam bentuk sosial tertentu. Oleh karena itu, penulis mengatakan bahwa modal sebagai penguasaan system pertukaran yang bentuknya sangat berharga berupa uang dan jenis barang lainnya yang di tukarkan hasilnya untuk mencapai tujuan, seperti kesejahteraan individu.

\subsection{Pendapatan}

Pendapatan merupakan suatu unsur penting dalam perekonomian yang berperan meningkatkan derajat hidup orang banyak melalui kegiatan produksi barang dan jasa (Tuankotta, 2013). Besarnya pendapatan seseorang tergantung dari jenis pekerjaannya. Pendapatan adalah segala sesuatu yang didapat dari hasil usaha baik berupa uang ataupun barang (Syahatah, 1998). Pendapatan merupakan jumlah seluruh uang yang diterima oleh seseorang atau rumah tangga selama jangka waktu tertentu (biasanya satu tahun).

Berdasarkan pengertian pendapatan yang telah disebutkan di atas, maka pendapatan yaitu besarnya pendapatan total pedagang yang diperoleh dari penjumlahan hasil dagang dengan pendapatan lainnya.

\section{METODE}

Penelitian kuantitatif (Prasetyo, 2012) yang digunakan penulis sebagai pengukuran angka dengan skala likert yang di berikan responden dengan pendekatan survey yang dianalisis secara deskriptif (Suwandi., 2008), di mana penelitian ini mendeskripsikan data angka-angka yang di translate kedalam argumentatif penulis (Maleong, 2006), untuk responden di tentukan dengan teknik sampling (Jannah., 2012) berupa rumus slovin dari populasi pedagang sebanyak 206 dengan galat error 5\% diketahui sebanyak 136 responden, sedangkan metode pengumpulan data (Mardikanto, 2010) digunakan kuesioner skala likert. 
Analisis regresi (Emsir., 2008) digunakan aplikasi SPSS 26 dengan pola pengujian pengaruh lokasi usaha, modal dan pendapatan secara parsial dan simultan terhadap kesejahteraan individu pedagang, selain itu, variable yang diteliti sebanyak empat (multivariate) (Ghozali, 2012) terdiri dari lokasi usaha, modal dan pendapatan sebagai variable bebas, kesejahteraan individu pedagang sebagai variable terikat.

Gambar 3. 1 Desain penelitian

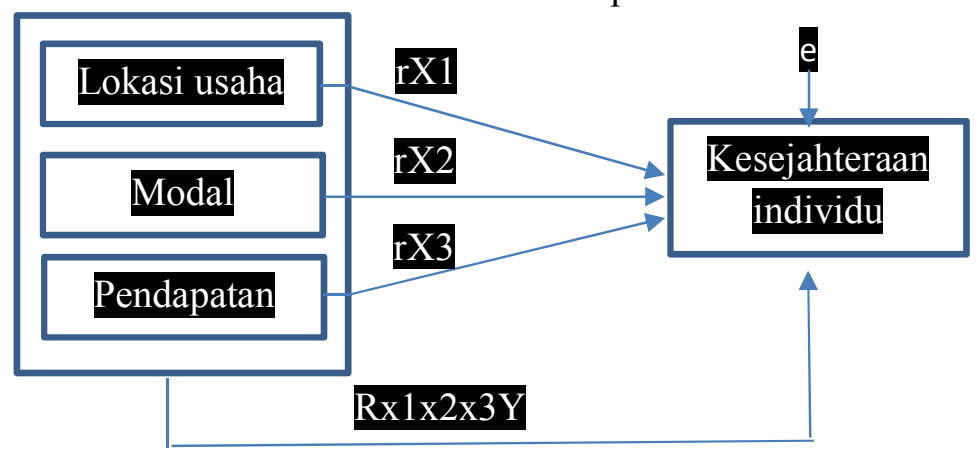

Keterangan :

$\longrightarrow \quad=$ Row (garis pengaruh)

$\mathrm{RxY}=$ Pengaruh parsial variable bebas terhadap variable terikat

$\mathrm{Rx} 1 \times 2 \times 3 \mathrm{Y}=$ Pengaruh simultan variable bebas terhadap variable terikat

$\mathrm{e}=$ Epsilon

\section{Hasil dan pembahasan}

Hasil pengolahan data yang dilakukan dengan menggunakan SPSS 26 yang telah di analisis sebagai berikut :

Uji validitas telah menguji butir instrument (Arifin, 2017) kuesioner variable penelitian sebagai uji keabsahan atau kesohehan data instrument yang layak di olah selanjutnya, sedangkan masing-masing butir kuesioner untuk variable lokasi usaha sebanyak 15 butir, modal sebanyak 15 butir dan pendapatan sebanyak 15 butir serta kesejahteraan individu pedagang sebanyak 15 butir sehingga jumlah keseluruhan butir kuesioner variable menjadi 60 butir kuesioner, untuk menyimpulkan data kuesioner valid, jika nilai sig, < 0,05 (5\%) (Siregar, 2015), di sajikan dalam rekapitulasi, sebagai berikut :

Tabel 2. 1 Hasil Pengujian Validitas

\begin{tabular}{|l|l|l|l|l|l|}
\hline No & \multicolumn{1}{|c|}{ Variable } & $\begin{array}{c}\text { Butir } \\
\text { kuesioner }\end{array}$ & $\begin{array}{c}\text { Butir } \\
\text { valid }\end{array}$ & $\begin{array}{c}\text { Proporsisi } \\
(5 \%)\end{array}$ & Keterangan \\
\hline 1 & $\begin{array}{l}\text { Lokasi usaha } \\
(\mathrm{X} 1)\end{array}$ & 15 & 13 & Sig $<0,05$ & Valid \\
\hline 2 & Modal (X2) & 15 & 12 & Sig $<0,05$ & Valid \\
\hline 3 & Pendapatan $(\mathrm{X} 3)$ & 15 & 12 & Sig $<0,05$ & Valid \\
\hline 4 & Kesejahteraan & 15 & 14 & Sig $<0,05$ & Valid \\
\hline
\end{tabular}




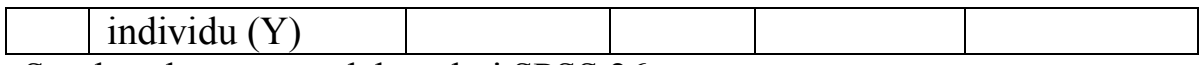

Sumber data : pengolahan dari SPSS 26

Berdasarkan hasil pengolahan data yang dianalisis skor kuesioner yang tidak valid di drop dan skor yang bernilai valid seluruhnya di analisis selanjutnya, maka butir instrument yang dapat dilanjutkan uji reliabilitas dengan skor gradasi 0,6 (diterima) sebagai batas minimal penerimaan (Riadi, 2016).

Uji reliabiltas yang diujikan datanya untuk membuktikan pengukuran mendapati reliabel (dapat diterima), untuk membuktikannya digunakan nilai alfha hitung $>0,06$ yaitu diterima (Riadi, Statistika Penelitian (Analisis Manual dan IBM SPSS), 2016), dapat di sajikan pada rekapitulasi sebagai berikut :

Tabel 2. 2 Hasil Pengujian Reliabilitas

\begin{tabular}{|l|l|l|l|l|l|}
\hline No & \multicolumn{1}{|c|}{ Variable } & $\begin{array}{l}\text { Butir valid } \\
\text { kuesioner }\end{array}$ & $\begin{array}{c}\text { Nilai } \\
\text { alfha }\end{array}$ & \multicolumn{1}{|c|}{ Interpretasi } & Keterangan \\
\hline 1 & Lokasi usaha (X1) & 13 & 0,774 & $0,6<\mathrm{a}<0,08$ & Diterima \\
\hline 2 & Modal (X2) & 12 & 0,793 & $0,6<\mathrm{a}<0,08$ & Diterima \\
\hline 3 & Pendapatan (X3) & 12 & 0,794 & $0,6<\mathrm{a}<0,08$ & Diterima \\
\hline 4 & $\begin{array}{l}\text { Kesejahteraan } \\
\text { individu (Y) }\end{array}$ & 14 & 0,651 & $0,6<\mathrm{a}<0,08$ & Diterima \\
\hline
\end{tabular}

Sumber data : pengolahan dari SPSS 26

Uji normalitas (Setiawan, 2015) sebagai sebaran data yang dianalisis berdistribusi normal, pengujian normalitas dilakukan dengan one sampel kolmogorov Smirnov test yaitu jika nilai Asymp sig (2-tailed) $>0,05$ diartikan data berdistribusi normal, dapat di sajikan rekapitulasi sebagai berikut :

Tabel 2. 3 Hasil Pengujian Normalitas

\begin{tabular}{|l|l|l|l|}
\hline No & \multicolumn{1}{|c|}{ Variable } & \multicolumn{1}{|c|}{$\begin{array}{c}\text { Nilai Asymp } \\
\text { sig (2-tailed) }\end{array}$} & \multicolumn{1}{|c|}{ Keterangan } \\
\hline 1 & Lokasi usaha (X1) & 0,110 & Normality \\
\hline 2 & Modal (X2) & 0.740 & Normality \\
\hline 3 & Pendapatan (X3) & 0,215 & Normality \\
\hline 4 & Kesejahteraan individu (Y) & 0,491 & Normality \\
\hline
\end{tabular}

Sumber data : pengolahan dari SPSS 26

Untuk hasil analisis regresi (Sujarweni, 2015) secara parsial dan secara simultan dimaksud sebagai pengujian kisaran besaran pengaruh antara variable lokasi usaha, modal dan pendapatan (variable bebas) terhadap kesejahteraan individu pedagang (variable terikat), rekapitulasi disajikan sebagai berikut :

Tabel 2. 4 Koefisien Determinasi (Anova)

\begin{tabular}{|l|l|l|l|l|}
\hline Model & \multicolumn{1}{|c|}{ Variabel } & Skor R & $\begin{array}{l}\text { Koefisien } \\
\text { determinasi }\end{array}$ & Keterangan \\
\hline 1 & $\begin{array}{l}\text { Lokasi usaha (X1) terhadap } \\
\text { kesejahteraan individu }\end{array}$ & 0,426 & $18,14 \%$ & $\begin{array}{l}\text { Positif dan } \\
\text { kuat }\end{array}$ \\
\hline
\end{tabular}




\begin{tabular}{|l|l|l|l|l|}
\hline & pedagang (Y) & & & \\
\hline 2 & $\begin{array}{l}\text { Modal (X2) terhadap } \\
\text { kesejahteraan individu } \\
\text { pedagang (Y) }\end{array}$ & 0,404 & $16,32 \%$ & $\begin{array}{l}\text { Positif dan } \\
\text { kuat }\end{array}$ \\
\hline 3 & $\begin{array}{l}\text { Pendapatan (X3) terhadap } \\
\text { kesejahteraan individu } \\
\text { pedagang (Y) }\end{array}$ & 0,404 & $16,32 \%$ & $\begin{array}{l}\text { Positif dan } \\
\text { kuat }\end{array}$ \\
\hline 4 & $\begin{array}{l}\text { Lokasi usaha (X1), Modal } \\
\text { (X2) dan Pendapatan (X3) } \\
\text { terhadap kesejahteraan } \\
\text { individu pedagang (Y) }\end{array}$ & 0,432 & $18,66 \%$ & $\begin{array}{l}\text { Positif dan } \\
\text { kuat }\end{array}$ \\
\hline
\end{tabular}

Sumber data : pengolahan dari SPSS 26

Berdasarkan tabel output model summary di atas, di ketahui Lokasi usaha (X1) terhadap kesejahteraan individu pedagang (Y) nilai $\mathrm{R}$ sebesar 0,426 yang berarti 18,14\% pengaruh Lokasi usaha (X1) terhadap kesejahteraan individu pedagang (Y). Nilai R sebesar 0,426 yang berarti 16,32\% pengaruh Modal (X2) terhadap kesejahteraan individu pedagang (Y). Nilai R sebesar 0,426 yang berarti 16,32\% pengaruh Pendapatan (X3) terhadap kesejahteraan individu pedagang (Y) dan Nilai R sebesar 0,432 yang berarti $18,66 \%$ pengaruh simultan Lokasi usaha (X1), Modal (X2) dan Pendapatan (X3) terhadap kesejahteraan individu pedagang (Y).

Tabel 2. 5 Regresi Berganda Uji F

\begin{tabular}{|c|c|c|c|c|c|c|}
\hline \multicolumn{7}{|c|}{ ANOVA $^{\mathrm{a}}$} \\
\hline \multicolumn{2}{|c|}{ Model } & $\begin{array}{l}\text { Sum of } \\
\text { Squares }\end{array}$ & df & Mean Square & $\mathrm{F}$ & $\mathrm{Sig}$ \\
\hline \multirow[t]{3}{*}{1} & Regression & 420.656 & 3 & 140.219 & 10.075 & $.000^{\mathrm{b}}$ \\
\hline & Residual & 1837.079 & 132 & 13.917 & & \\
\hline & Total & 2257.735 & 135 & & & \\
\hline
\end{tabular}

Sumber data : pengolahan dari SPSS 26

Karena nilai signifikansi pada uji $\mathrm{F}$ adalah nilai sig. $=0,000<0,05$. Maka $\mathrm{H} 1$ di terima dan $\mathrm{H} 0$ di tolak. Jika $\mathrm{H} 1$ di terima artinya terdapat pengaruh signifikan lingkungan usaha (X1), modal (X2) dan pendapatan (X3) secara simultan dapat diasumsikan memiliki pengaruh yang kuat dan signifikan terhadap kesehateraan individu pedagang (Y).

\section{Kesimpulan}

1. Lokasi usaha merupakan salah satu keputusan bisnis yang harus dibuat secara hati-hati, dimana untuk mencapai kesuksesan usaha pedagang yang diharapkan, dibuktikan dengan hasil pengujian pengaruh Lokasi usaha (X1) terhadap kesejahteraan individu pedagang (Y) sebesar 18,14\% berkategori positif dan kuat. 
2. Modal sebagai penguasaan system pertukaran yang bentuknya sangat berharga berupa uang dan jenis barang lainnya yang di tukarkan hasilnya untuk mencapai tujuan, seperti kesejahteraan individu. Dibuktikan dengan hasil pengujian regresi parsial pengaruh Modal (X2) terhadap kesejahteraan individu pedagang (Y) sebesar 16,32\% berkategori positif dan kuat.

3. Pendapatan ialah besarnya pendapatan total pedagang yang diperoleh dari penjumlahan hasil dagang dengan pendapatan lainnya untuk memenuhi kehidupan individu menjadi sejahtera, dibuktikan dengan hasil pengujian pengaruh pendapatan (X3) terhadap kesejahteraan individu pedagang (Y) sebesar 16,32\% berkategori positif dan kuat.

4. Kesejahteraan individu pedagang merupakan keinginan setiap manusia yang dapat di capai di dalam menjalankan rutinitas kegiatannya sering terpapar dengan kesusahan, kesulitan dan hambatan dari hasil yang maksimal, dibuktikan dengan hasil pengujian pengaruh simultan Lokasi usaha (X1), Modal (X2) dan Pendapatan (X3) terhadap kesejahteraan individu pedagang (Y) sebesar $18,66 \%$ berkategori positif dan kuat.

\section{DAFTAR PUSTAKA}

Abd. Azis, J. S. (2017). Implementasi Peraturan Presiden Nomor 112 Tahun 2007 Implementasi Peraturan Presiden Nomor 112 Tahun 2007, 128.

Arifin, J. (2017). Spss 24 Untuk Penelitian Dan Skripsi. Jakarta: Pt. Elex Media Komputindo.

Cahyono. (2014). Jurnal: Ekobis, 1 (15). Cahyono, B. (2014). Peran Modal Sosial Dalam Peningkatan Kesejahteraan Masyarakat Petani Tembakau Di Kabupaten Wonosobo. Jurnal: Ekobis, 1 (15), Hlm.1-16., 1-16.

Charty E, J. M. (1993). Dasar-Dasar Pemasaran . Jakarta: Erlangga Press.

Emsir. (2008). Metodologi Pendidikan : Kuantitatif Dan Kualitatif. Jakarta: Pt. Raja Grafindo Persada.

Ghozali, I. (2012). Aplikasi Analisis Multivariate Dengan Progran Ibm Spss 23. . Semarang: Badan Penerbit Universitas Di Ponegoro.

Irawan, B. S. (2005). Asas-Asas Marketing. Yogyakarta: Liberty Pres.

Jannah., B. P. (2012). Metode Penelitian Kuantitatif Teori Dan Praktik. Jakarta: Rajawali Pers.

Jauhari. (2009). Bunga Rampai: Pemikiran Hukum Di Indonesia. "Politik Hukum Negara Kesejahteraan Indonesia (Studi Tentang Kebijakan Regulasi Dan Institusionalisasi Gagasan Kesejahteraan Sosial Ekonomi Masyarakat Nelayan Di Jawa Tengah). Fh Uii Press Yogyakarta, 320.

Kustiadi, H. W. (2017). Indokator Kesejahteraan, Indikator Berkelanjutan Lingkungan Hidup Dan Impelementasi Nya Di Indonesia . Jakarta Pusat: Pusat Penelitian Badan Keahlian Dpr Ri.

Maleong. (2006). Metodologi Penelitian Kualitatif. Bandung: Remaja Rosdakarya. 
Mardikanto. (2010). Metoda Penelitian Dan Evaluasi Pemberdayaan Masyarakat. Untuk Akademisi, Praktisi, Dan Peminat Pemberdayaan Masyarakat. Surakarta: Program Pasca Sarjana Universitas Sebelas Maret Press.

Prasetyo, B. D. (2012). Metode Penelitian Kuantitatif Teori Dan Praktik. Jakarta: Rajawali Pers.

Riadi, E. (2016). Metode Penelitian Kuantitatif SPSS. Yogyakarta: Andi Offset.

Riadi, E. (2016). Statistika Penelitian (Analisis Manual Dan Ibm Spss). Yogyakarta: Andi Offset.

Setiawan, B. (2015). Teknik Praktis Analisis Data Penelitian Sosial Dan Bisnis Dengan Spss. Yogyakarta: Andi Offset.

Siregar, S. (2015). Statistik Parametrik Untuk Penelitian Kuantitatif Dilengkapi Dengan Perhitungan Manual Dan Aplikasi Spss Versi 17. Jakarta: Pt. Bumi Aksara.

Siti, N. F. (2014). Pengelolaan Pasar Tradisional Berbasis Musyawarah . Jurnal Fakultas Ekonomi Dan Bisnis: Universitas Muhammadiyah Surakarta, 50.

Suandi. (2007). Modal Sosial Dan Kesejahteraan Ekonomi Keluarga Daerah Pedesaan Provinsi Jambi [Disertasi]. Bogor (Id): Institut Pertanian. Bogor: Institut Pertanian Pres.

Sudriwati. (2017). Dampak Keberadaan Pasar Kaget Terhadap Pendapatan Pedagang Pasar Kiyap Jaya Ditinjau Menurut Ekonomi Islam (Studi Kasus Pasar Kiyap Jaya Kab Pelalawan). Riau: Uin Suska Riau.

Sujarweni, V. W. (2015). Statistik Untuk Bisnis Dan Ekonomi. Yogyakarta: Pustaka Baru Press.

Sumaatmadja, N. (2008). Studi Geografi : Suatu Pendekatan Dan Analisa Keruangan . Bandung: Remaja Rosdakarya.

Suwandi., B. D. (2008). Memahami Penelitian Kualitatif. Jakarta: Rineka Cipta.

Swastha, B. (1990). Manajemen Penjualan. Yogyakarta: Fakultas Ekonomi Universitas Gajah Mada Pres.

Syahatah, H. (1998). Ekonomi Rumah Tangga Muslim. Jakarta: Gema Insani Press.

Tuankotta, T. M. (2013). Mendeteksi Manipulasi Laporan Kuangan. Jakarta: Salemba Empat.

Yusanto, M. I. (2000). Paradigma Sistem Ekonomi Islam. Yogyakarta: Umy Jesp Vol 1 No 2 Oktober 2000 Hlm 124-130.

Zela, A. T. (2019). Konflik Peran Ganda Terhadap Kesejahteraan Subjektif Pada Perawat Wanita Di Kota Curup. Inderalaya: Jurnal Program Studi Psikologi Universotas Sriwijaya Inderalaya. 